\title{
短報
}

\section{香川県綾川町ボーリングコアの花粉分析による 最終水期以降の古植生}

\author{
松居 俊典*1,a 石塚 正秀*1 ・ 此松 昌彦*2
}

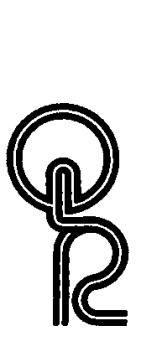

香川県綾歌郡綾川町の綾川中流域で採取した $8 \mathrm{~m}$ のボーリングコアを岩相に基づいて下位よ り 9 層 (No. 9 No. 1) に区分し, 年代測定, 花粉分析を行った. 年代測定結果から, コア深度 $8.00 \sim 3.55 \mathrm{~m}$ は上部更新統, コア深度 $3.55 \mathrm{~m}$ より上部は完新統と判明した. 花粉分析結果から, 最終水期中期はQuercus subgen. Lepidobalanus (コナラ属コナラ亜属) を主とする落葉広葉樹 林が分布する冷涼な環境が, 後水期前期はQuercus subgen. Cyclobalanopsis (コナラ属アカガシ 亜属）を含む落葉広葉樹林主体のやや冷涼な環境が，そして後水期後期には温帯針葉樹を含む Cyclobalanopsis 優占の照葉樹林が分布する温暖な環境が推定できた.この傾向は既存の瀬戸内 地域における古植生研究の結果とおおむね扔致する。この地域の特徵として, 後水期後期には Castanopsis (シイ属) がほとんど産出しない。これは, この地域の試料採取上流域からのCastanopsis 供給が少なく, 瀬戸内海地域の中でも年間降水量が 1, $200 \mathrm{~mm}$ 以下と少ない乾燥した地 域であるためと考えられる.

キーワード : 花粉分析, 最終水期, 後氷期, 古環境, 綾川町

\section{I. は じめに}

花粉化石を用いて過去の植生を解明した研究は数多く あるが, 瀬戸内地域の平野部は乾燥した気候で, 湿地環 境が少なく, 開発も進んでいるために, 連続した保存状 態のよい花粉分析用試料の入手が困難である. そのた め, 最終水期の試料を含む研究は他地域に比べて少な く, 児島湾 (三好, 1994), 頭島 (Fujiki et al., 1998), 鳴 門市 (板野ほか, 1994), 香川県では引田町 (坂東・古市, 1972) および高松市・丸亀市 (古市, 1980)において行わ れている程度である(図 1)。しかし, 坂東・古市 (1972) の研究では更新世の試料から花粉がほとんど出ておら ず，また古市 (1980) ではお屯に新第三系の美鋀層群の 存在をMetasequoia (メ夕セコイヤ属)によって確認し ている. 一方, 後水期以降の研究は燧灘 (藤木ほ玏, 1995) と三木町 (杉山ほか, 2001) などで行われているが, 瀬戸 内域の古植生を考察するためには, より多くの研究が必

2009 年 6 月 26 日受付. 2011 年 10 月 13 日受理.

*1 香川大学工学部 =761-0396 高松市林町 2217-20.

$* 2$ 和歌山大学教育学部 $\mathbf{\%} 640-8510$ 和歌山市栄谷 930 .

*a Corresponding author : matsui@ao.kagawa-u.ac.jp
要である. 本研究は, 香川県の中讃地域を流れる綾川中 流域で採取したボーリングコアの花粉分析から, 最終水 期以降の古植生を復元し, 当時の環境の推定を行う.

\section{II. 調查地の概要}

\section{1. 調査地の地形と地質概説}

香川県の地形・地質は, 和泉層群よりなる讃岐山脈, 領家帯の花崗岩類および讃岐層群からなる丘陵地や山塊 群, 三豊層群および焼虐岻碩層からなる台地, 沖積低地 および低位段丘からなる讃岐平野の 4 つに分類される (長谷川・斉藤，1989）.

本研究の試料採取地点は, 香川県綾歌郡綾川町の北地 区 (北緯 $34^{\circ} 13^{\prime} 57^{\prime \prime}$, 東経 $133^{\circ} 56^{\prime} 04^{\prime \prime}$ ) に位置する (図 1a). 海岸線から約 $15 \mathrm{~km}$ 内陸の二級河川である綾川の中 流域で標高は約 $50 \mathrm{~m}$ である. 5 万分の 1 土地分類基本 調查の地形分類図「丸亀」(経済企画庁, 1967) によると, この地域は谷底平野および汇濫原であり, 洪水時に冠水 
する地域に分類される. 調查地の周辺部は更新世中期〜 後期の台地に囲まれており, 約 $100 \mathrm{~m}$ 南側に綾川が流れ ている(図 1-b). 綾川の本線指定延長は香川県下最長の $38.2 \mathrm{~km}$ であり, 流域面積は $137.5 \mathrm{~km}^{2}$ である.

\section{2. 調査地の気候と植生}

香川県は瀬戸内式気候に属しており, 調査地のある綾 川町内の気象庁のアメダス観測所の滝宮 (図 1-b)では, $1979 \sim 2000$ 年の平均降水量は $1,147.5 \mathrm{~mm}$, 平均気温は

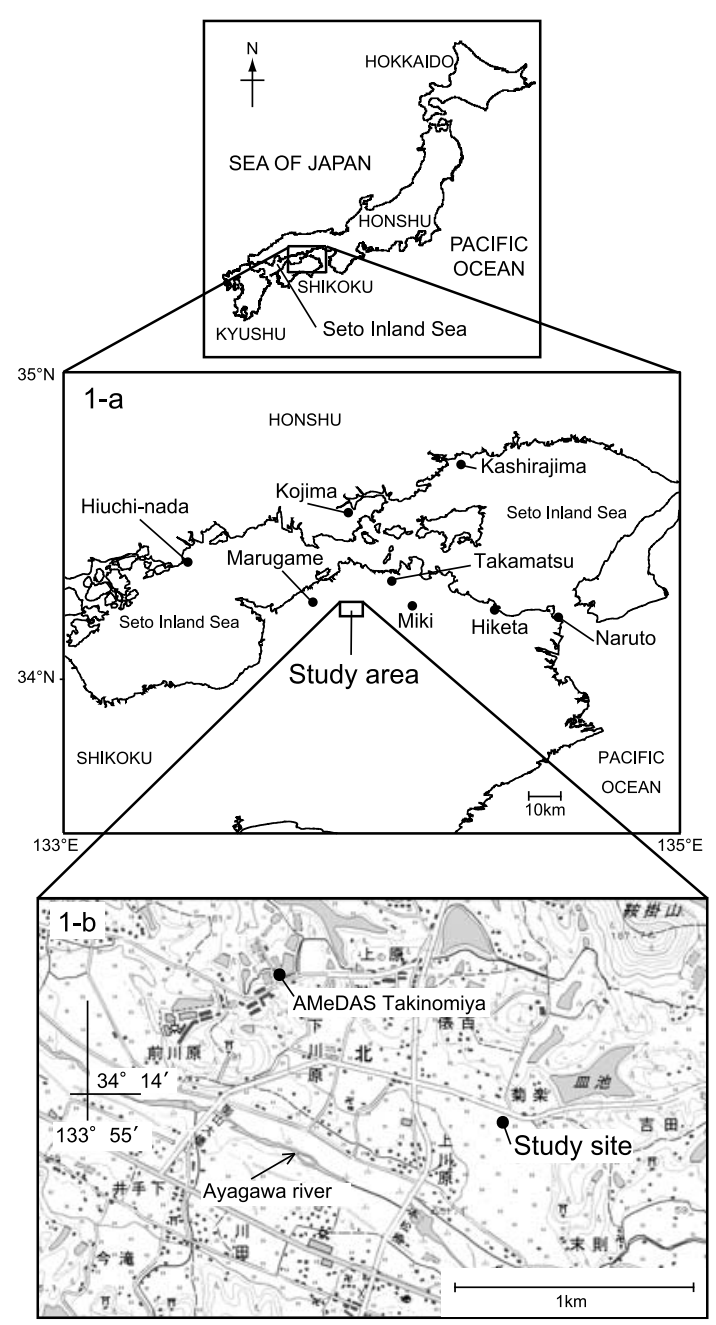

図 1 調 查地点

図 1-b は国土地理院 1/25000 地形図「滝宮」を使用.

Fig. 1 Location maps of the study site $1-\mathrm{b}$ is modified from the $1 / 25000$ topographic map of Takinomiya issued by the Geospatial Information Authority of Japan. $14.9^{\circ} \mathrm{C}, 1987 \sim 2000$ 年の平均日照時間は $1,750.5 \mathrm{~h}$ であ る(高松地方気象台，2009），そこで，吉良 (1948) に基づ いて暖かさの指数を算出すると, $119.8^{\circ} \mathrm{C} ・$ 月となる.

香川県の植生分布は, 標高約 $400 \mathrm{~m}$ が照葉樹林帯上部 と下部の境界, 標高約 $790 \mathrm{~m}$ が照葉樹林帯上部と温帯落 葉樹林帯の境界となる (奥田, 1982 ; 末広, 1982, 2007). しかし, 香川県では低地や丘陵地の大部分が開発されて おり, 全面積の $90 \%$ 以上が代償植生で覆われている. そ のために, 常緑広葉樹が優先する照葉樹林は社寺林に断 片的に残っているにすぎない. 自然植生に近い代償植生 あごく限られ, Pinus (マツ属) や Cryptomeria (スギ属), Chamaecyparis (ヒノキ属) などの針葉樹林が沖積低地 を除く香川県全域に広範囲に広がっている（奥田, 1982 ; 末広, 1982, 2007). 瀬戸内地域の潜在自然植生は, 降水 量が少なく乾燥しているために, Machilus (タブノキ属) 林の発達がみられない (山中, 1979). 服部 (1992) は $M a$ chilus 林のみならず, Machilus 単木の分布も稀である と報告している. また, 岸本ほか (1978) は Castanopsis (シイ) 属林において, 温暖かつ湿性な種が脱落するとい う組成的な特徵があると報告している.

\section{III. 試料採取と処理方法}

\section{1. ${ }^{14} \mathrm{C}$ 年代測定および花粉分析試料の採取}

ボーリングは D-1B 型油圧式試錐機（東邦地下工機 (株) 製)を用いて, ロータリー式ボーリング工法にて 行った. ボーリングコアは岩相により, 下位からNo. 9 No. 1 のつに区分した. 年代測定用試料は合計 7 試料 を採取した. また，花粉分析用試料はそれぞれの岩相か ら, 1 試料あたり約 $50 \mathrm{~g}$ で合計 12 試料を採取した (図 2).

\section{2. ${ }^{14} \mathrm{C}$ 年代測定試料処理方法}

${ }^{14} \mathrm{C}$ 年代測定は (株)地球科学研究所に依頼し, 測定は AMS 法により行った. 暦年代は年代既知の樹木年輪の ${ }^{14} \mathrm{C}$ を測定し, サンゴの U-Th 年代との比較により補正 曲線から算出した. 使用したデータセットはIntcal04 (Reimer et al., 2004)である. 採取した 7 試料はすべて 乾燥試料であり, コア深度 $6.84 \mathrm{~m}$ の試料のみ木片を酸アルカリ-酸洗浄で前処理を行い, それ以外の 6 試料は 有機質堆積物を酸洗浄で前処理を行い測定した.

\section{3. 花粉分析試料処理方法}

はじめに試料表面の洗浄を行い, 小豆くらいの大きさ に砕き, 砕いた試料は $10 \% \mathrm{KOH}$ 水溶液に浸して泥化さ せてフミン酸・粘土鉱物を遊離させた. 次に蒸留水を加 えて傾瀉法によりフミン酸・粘土鉱物を除去した.さう に, $\mathrm{HF}$ で珪酸質を除去し, $\mathrm{ZnCl}_{2}$ 重液で残った粘土鉱物 


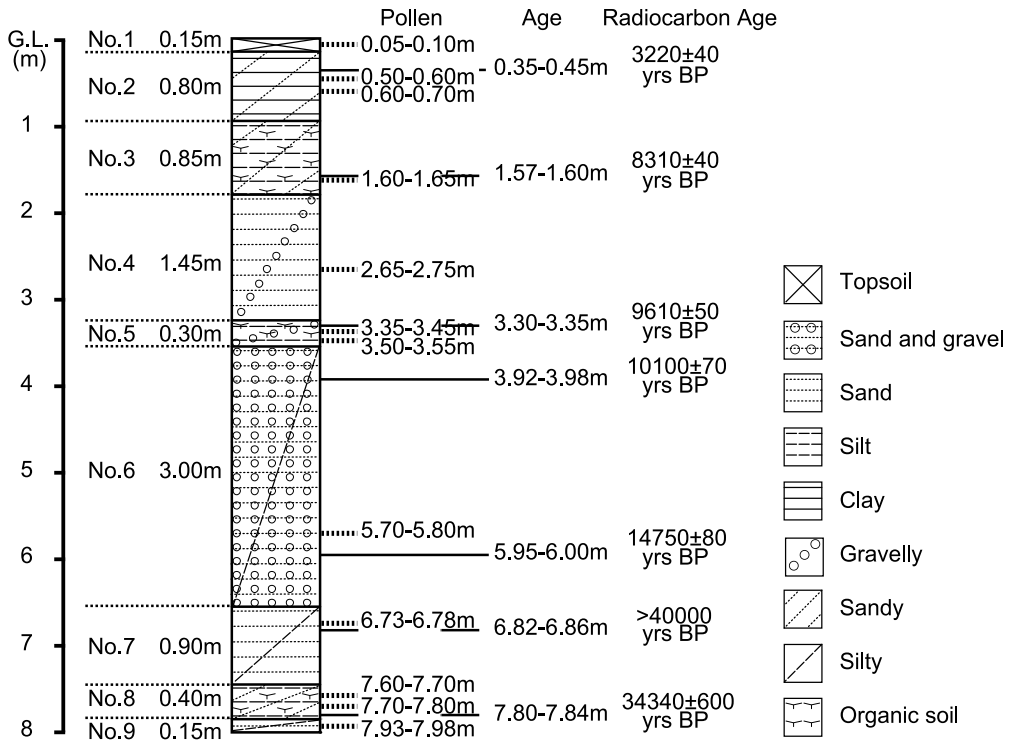

図 2 地質柱状図と花粉・年代測定試料採取層準

図中の No. 1〜No. 9，0.15 m などは岩相区分とその厚さを示す.

Fig. 2 Geological column, pollen sampling horizons, and radiocarbon dating results

と有機物を比重分離させ，アセトリシス処理でセルロー スを分解して花粉を濃縮させた. 最後に, グリセリンゼ リーを加えてプレパラートを作成した.

検鏡は光学顕微鏡の倍率を 400 倍で行った，木本花粉 粒が 250 個以上同定に達した試料に対して, 古植生を推 定した. 出現率は木本花粉の総数を基数として百分率で 示す. また, シダ植物の胞子化石は同定を行わなかった.

\section{IV. 結 果}

\section{1. 綾川町ボーリングコアの年代測定結果}

${ }^{14} \mathrm{C}$ 年代測定結果は, コア深度 $0.40 \mathrm{~m}$ で $3,220 \pm 40$ yrs BP, $1.58 \mathrm{~m}$ で $8,310 \pm 40 \mathrm{yrs}$ BP, $3.33 \mathrm{~m}$ で 9,610 \pm 50 yrs BP, $3.95 \mathrm{~m}$ で $10,100 \pm 70$ yrs BP, $5.98 \mathrm{~m}$ で $14,750 \pm 80$ yrs BP, $6.84 \mathrm{~m}$ で> $40,000 \mathrm{yrs} \mathrm{BP}, 7.82 \mathrm{~m}$ で $34,340 \pm 600$ yrs BP であった (図 2)。また, ${ }^{14} \mathrm{C}$ 年代 值を較正した暦年代 $(2 \sigma)$ は, コア深度 $0.40 \mathrm{~m}$ で 3,520 $\sim 3,550$ cal BP, $1.58 \mathrm{~m}$ で 9,250 9,440 cal BP, $3.33 \mathrm{~m}$ で $10,740 \sim 11,180$ cal BP, $3.95 \mathrm{~m}$ で $11,330 \sim 12,040$

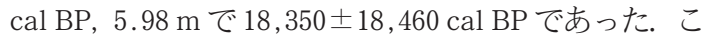
のことから, 岩相 No. 6 より下部は更新統の段丘堆積物, 岩相 No. 5 より上部は完新統となる. なお, 岩相 No. 7 と 岩相 No. 6 の境界 (コア深度 6.55 m) には最終水期最盛 期から後水期初期までの堆積物が欠落している.

\section{2. 花粉分析結果と古植生および古環境}

綾川町ボーリングコアの全層準 12 試料をあわせて, 木本花粉 24 種, 草本花粉 9 種が産出した. これらの花粉 化石の出現率を図 3 に示す。岩相 No. 4 と岩相 No. 6 に は, 磁が多く含まれ, 花粉が産出しなかった。 また, 岩 相 No. 9 では花粉の保存状態が悪く, 同定できなかっ た. したがって, 花粉が同定された層準は, AP8-1, AP 8-2, AP7-1, AP5-1, AP5-2, AP3-1, AP2-1, AP2-2, AP1-1 の計 9 試料である. なお, AP3-1 と AP7-1 は木 本花粉が 250 個に達しなかったため, 参考デー夕とする (表 1).

最終水期中期 (AP8-1，AP8-2)：落葉広葉樹林が優勢 であり, Quercus subgen. Lepidobalanus (コナラ属コナ ラ亜属) が 38〜19\%, Juglans (クルミ属) が 18〜15\% 産 出した. また, Pinus subgen. Haploxylon (マツ属単維管 束亜属) が $1 \%$ 程度みられ，冷涼な環境であったと考え られる。

後水期前期 (AP5-1, AP5-2)：Lepidobalanus が 25〜 15\%, Celtis-Aphananthe (エノキームクノキ属)が 14 13\% 産出した. AP5-1ではQuercus subgen. Cyclobalanopsis (コナラ属アカガシ亜属) が $27 \%$ と多く産出したが, 落 葉広葉樹林主体の古植生がみられ，やや冷涼な環境で あったと考えられる. 


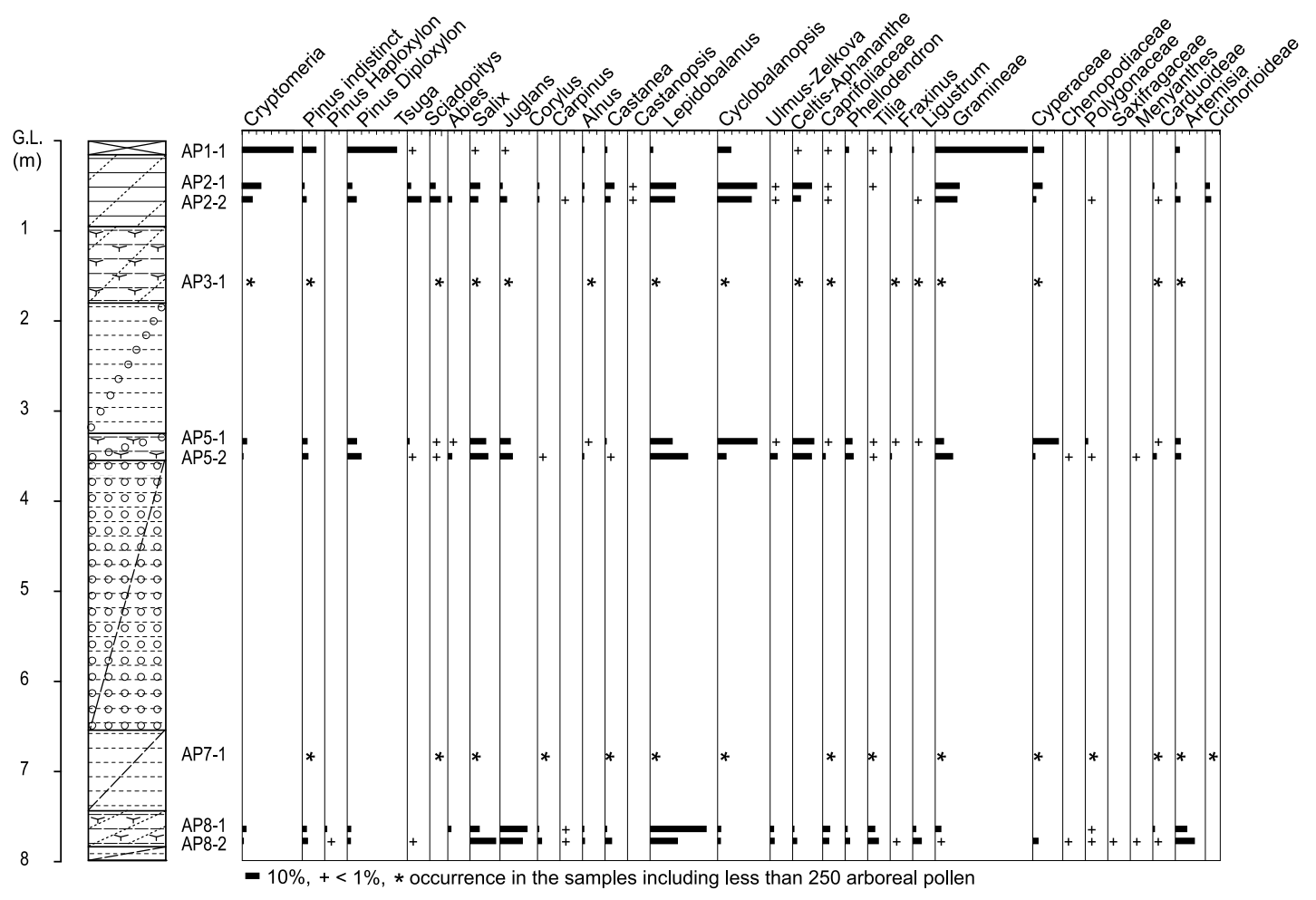

図 3 綾川町ボーリングコアの花粉ダイアグラム 柱状図の凡例は図 2 と同じ.

Fig. 3 Occurrence of pollen in sediments of the drilling core from Ayagawa town, Kagawa Prefecture Explanatory note of geological column are the same as Fig. 2.

表 1 香川県綾川町ボーリングコアから産出した花粉化石

Table 1 Fossil pollen results for a drilling core from Ayagawa town, Kagawa Prefecture

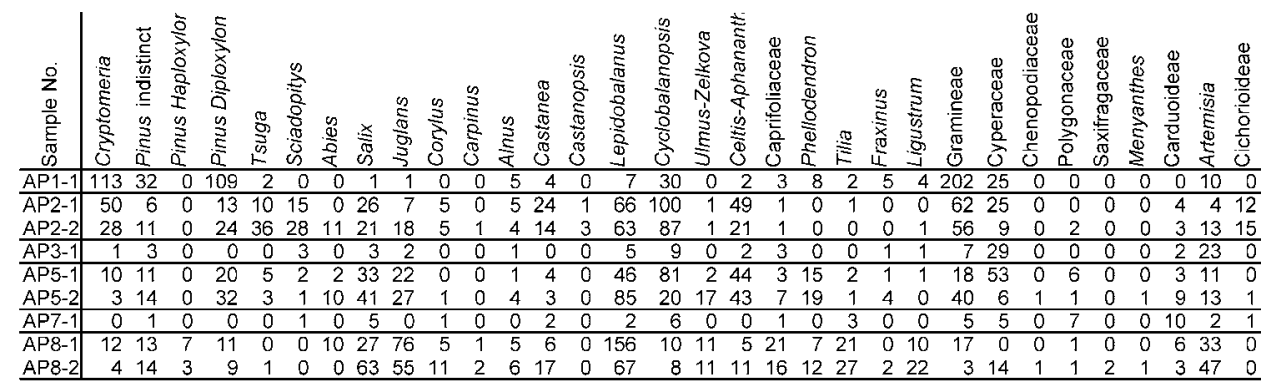

後水期後期 (AP2-1, AP2-2)：照葉樹林がやや優勢で あり,Cyclobalanopsis が 26〜23\%産出した. 1\%以下 であるが, Castanopsis あ産出した. 落葉広葉樹は Lepidobalanusが 17\%, Celtis-Aphananthe が 13〜6\%, Castanea (クリ属) が 6〜4\% 産出し, Cryptomeria, Tsuga (ツガ属), Sciadopitys (コウヤマキ属), Pinus subgen.
Diploxylon (マツ属複維管束亜属) などの針葉樹もみら れた. 後氷期後期の気温低下の傾向がみられるが，比較 的に温暖な環境であったと考えられる.

Castanopsis と Castanea の判別は光学顕微鏡では難 しいとされるが, 本研究では現生標本と見比べながら, 溝の厚みが孔に向かって厚くなっているかどうかを判断 


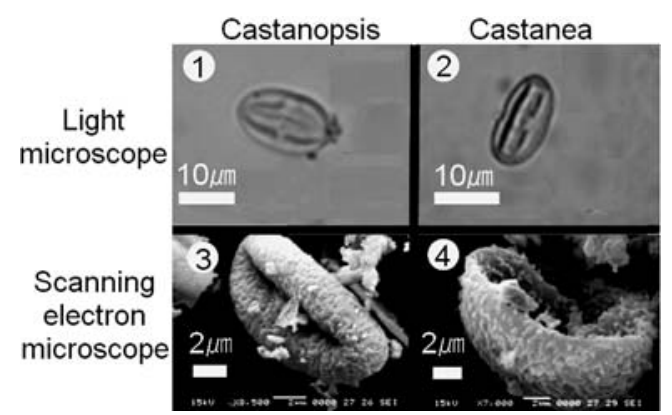

図 4 Castanopsis 之Castanea の光学顕微鏡像之 走査型電子顕微鏡像 (AP2-2 層準)

1, 3. Castanopsis, 2, 4. Castanea. 1, 2. 光学顕微鏡像, 3 , 4. 電子顕微鏡像.

Fig. 4 Light and scanning electron microscope images of Castanopsis and Castanea in the AP2-2 sample 1, 3 : Castanopsis, 2, 4 : Castanea.

基準にした. また, 走查電子顕微鏡で代表的な Castanopsis と Castanea と考えられる花粉を検鏡した. 同定は三 好 $(1981 ， 1982)$ を参考に, 外層の糸状の線と $0.1 \mu \mathrm{m}$ 前 後の微細な顆粒の有無で判別した (図 4).

現在 (AP1-1): Cryptomeria が 34\%, Pinus subgen. Diploxylon が 33\% と優勢であった. 草本花粉の割合は $72 \%$ であり, うち Gramineae (イネ科) が $62 \%$ 産出し た. 後水期後期と比較して, Cyclobalanopsis が減少, Cryptomeria, Pinus subgen. Diploxylon が増加してい る. これは人為的な開発による二次林的植生や植林によ ると考えられる. 綾川の中・上流域が含まれる自然環境 保全基礎調査植生調査 (環境省, 2001) の 2 次メッシュ

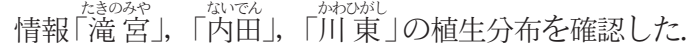
市街地や水域を除いた面積を基数とした割合で, 植林の Cryptomeria, Chamaecyparis が 10\%, 二次林であるPinus が37\%, Quercusが 17\%分布していた. 花粉分析結果 ではCryptomeria がやや過大に産出したが, 整合性が確 認できた.

\section{V. 考察}

\section{1. 綾川町の古植生と既往研究との比較}

綾川町の古植生と, 瀬戸内地域の既往の花粉分析によ る古植生を比較する.

最終水期中期 (AP8-1, AP8-2) : 児島湾 (三好, 1994) や頭島 (Fujiki et al., 1998) では, Lepidobalanus, UlmusZelkova (ニレーケヤキ属)などが優占している. また, 綾 川町において Cyclobalanopsis が少量産出することは児
島湾 (三好，1994) の結果と一致する.

後水期前期 (AP5-1，AP5-2)：児島湾 (三好，1994）で はLepidobalanus, Ulmus-Zelkova, Celtis-Aphananthe, Cyclobalanopsis などが優勢であり, 本研究と一致する. 頭島 (Fujiki et al., 1998)では両地域に比べて Cyclobalanopsis が少なく, Lepidobalanus が優勢である. Fagus (ブナ属)やCarpinus (クマシデ属)なども産出し，やや 冷涼な傾向がみられた. また, 西日本の後水期初期 (R I ) の特徵であるCeltis-Aphananthe が優勢することは一 致する.

後水期後期 (AP2-1，AP2-2)：児島湾 (三好，1994）, 三木町 (杉山ほか, 2001) では, Cyclobalanopsis が優勢 であり, Lepidobalanus, Tsuga が比較的多く, Castanopsis が少ないことについて, よい一致がみられた.

Lepidobalanus, Tsuga が比較的多いことは西日本の後 水期後期前半 (R III a) の気温低下の傾向であると考えら れる. しかし, 頭島 (Fujiki et al., 1998), 鳴門 (板野ほか, 1994), 燧灘(藤木ほか, 1995) では, Castanopsis が優勢 となり, 産出の傾向が同じ瀬戸内地域のほぼ同時期で違 いが生じている.

2. 後氷期後期の瀬戸内地域における Castanopsis の発達と年間降水量と暖かさの指数との関係

後水期後期における Castanopsis の花粉化石出現の有 無について，年間降水量と暖かさの指数に着目して図 5 を作成した. 図 5 には, 香川県の社寺林のCastanopsis cuspidata の分布之年間降水量 $1,200 \mathrm{~mm}$ 以上の地域, および暖かさの指数が $100^{\circ} \mathrm{C} \cdot$ 月以下の地域を重ねた結 果を示した. 年間降水量と暖かさの指数を算出するため に使用した平均気温には, メッシュ気候值 2000 (気象庁, 2002）を用いた. 降水量デー夕は降水量を目的変数とし て, 地形因子を説明变数とする重回帰式を多変量解析に

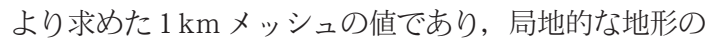
効果か降水量の推定に考慮されている.

成瀬ほか (1985) によると, 後水期後期の播磨灘の海 水準は現在と比べて $0 \sim 3 \mathrm{~m}$ 程度高かったと報告されて いる. しかし, 後水期後期の地形は現在と大きく変化し ていないと考えられることから, 降雨特性屯変化してい ないと推定される. また, 吉良ほか (1979) は, 日本の照 葉樹林帯下部之上部では, 暖かさの指数が $100 \sim 105^{\circ} \mathrm{C} \cdot$ 月以下の条件では Castanopsis が分布しないとして区分 している，なお，図 5 に示した暖かさの指数が $100^{\circ} \mathrm{C}$ ・ 月以下の範囲は, 四国山地および中国山地の標高 $300 \mathrm{~m}$ よりも高い地域に分布しており, 小豆島と岡山県のごく 一部を除くと, 年間降水量が $1,200 \mathrm{~mm}$ 以上の地域と重 


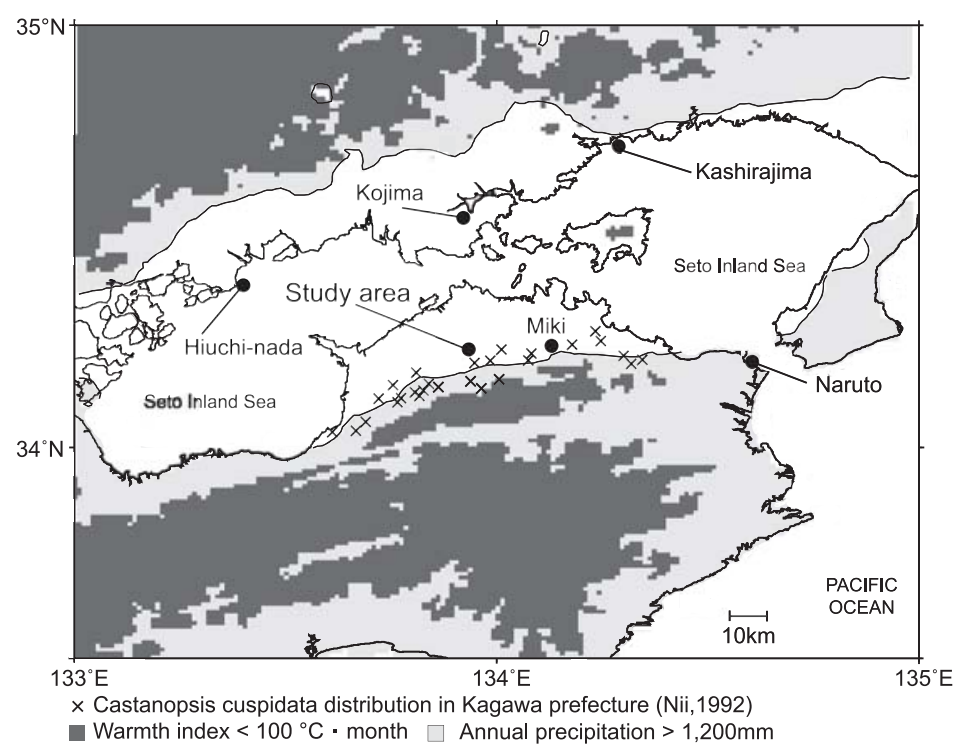

図 5 香川県の社寺林におけるッブラジイの分布 (新居, 1992) と年間降水量 および暖かさの指数 (吉良, 1948) との関係 年間降水量と平均気温は気象庁 (2002) を使用.

Fig. 5 Distribution of Castanopsis cuspidata in Kagawa Prefecture (Nii, 1992) in relation to annual precipitation and the warmth index (Kira, 1948) Annual precipitation and mean temperature data are from the Japan Meteorological Agency (2002).

なっている.

位田・波田（2006）は，岡山県中南部の社叢林の植生 と気候や降水量などの環境要因の関係を調査し，年間降 水量が 1,500 $\mathrm{mm}$ 以上の地域に Castanopsis sieboldii (スダジイ) が分布しており，1,400 1,600 mm の地域 には Castanopsis cuspidata (ツブラジイ)が分布してい ると報告している．ここで，年間降水量のデー夕には岡 山県メッシュ気候図 (岡山県, 1988) が用いられており, 本研究で用いたメッシュ気候值 2000 と異なる. そこで 両者を比較すると, 岡山県メッシュ気候図の年間降水量 $1,400 \mathrm{~mm}$ の境界は, メッシュ気候值 2000 の年間降水量 1,100 1,300 mm の範囲にあり， 1,200 mm の境界とお おむね致することがわかった。

久米ほか (1987) は, 香川県では豊島以外の Castanopsis はすべて Castanopsis cuspidata であると報告して いる. また, 新居 (1992) は香川県の 382 力所の社寺林を 調査し, うち 28 力所の社寺でCastanopsis cuspidata の 分布を確認している。 そこで, 香川県の社寺林における Castanopsis cuspidata の分布之年間降水量および暖か さの指数の分布を重ねてみると(図 5), Castanopsis cuspidata はおおも年間降水量 $1,200 \mathrm{~mm}$ の境界に沿っ て分布し， かつ暖かさの指数が $100^{\circ} \mathrm{C} \cdot$ 月以上の場所に 分布することが明らかとなった，この結果は，吉良ほか （1979）や位田・波田（2006）が示した条件之一致する. したがって, 図 5 の明灰色の範囲において Castanopsis が分布可能であると考えられる。

同じ瀬戸内地域であっても，鳴門 (板野ほか, 1994)で はCastanopsis が多く出現している. この理由は, 花粉 分析試料採取地力年間降水量 $1,200 \mathrm{~mm}$ 以上，かつ暖か さの指数が $100^{\circ} \mathrm{C}$ ・月以上の範囲にあるためと考えられ る. 一方, 花粉分析試料採取地力゙年間降水量 $1,200 \mathrm{~mm}$ に満たない地域は綾川町，燧灘(藤木ほか，1995), 頭島 (Fujiki et al., 1998), 児島湾 (三好, 1994), 三木町 (杉山 ほか，2001）がある(図 5)。この中で, Castanopsis が多 〈産出する地点は頭島と燧灘である．頭島の約 $4 \mathrm{~km}$ 離 れた対岸の本州側では, 年間降水量が 1,200 $\mathrm{mm}$ 以上, かつ暖かさの指数が $100^{\circ} \mathrm{C} \cdot$ 月以上の地域が広がり, 小 規模ではあるが瀬戸内海に流れ込む河川がある，同様 に, 遂灘の試料は煫灘というよりも備後灘で採取され, すぐ傍に一級河川の芦田川が流入している，頭島と燧灘 
と屯に年間降水量が $1,200 \mathrm{~mm}$ 以上，かつ暖かさの指数 が $100^{\circ} \mathrm{C}$ ・月以上の地域を流下する河川を通じた物質輸 送によって Castanopsis が多く出現したと考えられる. これに対して, 児島湾の試料は浅瀬の堆積物であるが, 採取地点が内湾の奥側に位置するため, 河川からの堆積 物の供給が少なく(佐々木・鈴木, 1998), Castanopsisの 出現が少なかったと考えられる. 綾川町之三木町におい て Castanopsis の産出が少なかった原因は, 試料採取地 点の上流域に Castanopsis の分布可能な地域力浃いため であると考えられる.

以上のことから, 綾川町の試料は乾燥する瀬戸内海地 域の中でも降水量が少なく, 丘陵地に囲まれた内陸の平 野部の植生を反映していると考えられる.

\section{VI. ま と め}

本研究は, 香川県綾歌郡綾川町北地区で採取したボー リングコアの花粉分析から, 古植生を復元し, 当時の環 境を検討した. 年代測定の結果では, 最終水期最盛期か ら後水期初期まで空白があるが, 約 $3 \sim 4$ 万年前以降か らの堆積物であることがわかった. 花粉分析結果から, 最終水期中期は冷涼な環境, 後水期前期はやや冷涼な環 境, 後水期後期は温暖な環境を示す植生が復元できた.

綾川町のボーリングコアの花粉分析結果の特徵は, 後 水期後期に Castanopsis がほとんど産出しないことであ る. その理由は, 瀬戸内海地域の中で年間降水量が $1,200 \mathrm{~mm}$ 以下と少なく, 乾燥する内陸の平野部の植生 を反映しているためと推定した. 上記の特徵以外は, 既 存の瀬戸内地域の研究結果とよく一致した.

謝辞 本研究の花粉試料採取と花粉分析処理には, 元 香川大学工学部安全システム建設工学科石塚研究室の田 中康史氏 (現栃木県警察), 前田耕輔氏 (現四国旅客鉄道 株式会社)にご協力いただいた。. また，年代測定につい ては, 香川大学工学部の長谷川修一教授にご指導いただ いた. 植生図の GIS 処理については, 香川大学工学部の 野々村敦子准教授にご指導いただいた. 調査地の使用に ついては香川県にご協力いただいた，本論文中における 図の一部は, GMT (Wessel and Smith, 1998)を用いて 作成した. 本研究は, 日本学術振興会科学研究費補助金 若手研究 (B)「花粉を用いた流域水環境变化と河川水・ 地下水の挙動の解明に関する研究」(課題番号: 18760378, 代表者: 石塚正秀) による資金援助をいただいた.ここ に謝意を表します.

\section{引用 文 献}

坂東祐司・古市光信 (1972) 四国北部の沖積平野におけ る第四系の花粉学的・層序学的研究一その 2-香川県 引田町における沖積堆積物の花粉学的研究. 香川大学 教育学部研究報告第 II 部, no. 215, 1-15.

藤木利之 ·三好教夫 - 中村隆昭（1995）海底堆積物の花 粉分析学的研究 1. 燧灘 (愛媛県). 岡山理科大学紀要, no. 30, 153-159.

Fujiki, T., Morita, Y. and Miyoshi, N. (1998) Vegetational history of the area around Kashira Island in the Inland Sea, Okayama Prefecture, weatern Japan. Quaterly Journal of Geography, 50, 189-200. 古市光信 (1980) 香川県高松・丸亀平野ボーリング・コ アの花粉分析 (予報) 一特に三豊層の再確認とその地 質年代について一. 香川県自然科学館研究報告, 2, 2532.

長谷川修一・斉藤 実（1989）讃岐平野の生いたち一第 一瀬戸内類層群以降を中心に一. アーバンクボ夕, no. 28, 52-59.

服部 保 (1992) タブノキ型林の群落生態学的研究 I. タブノキ林の地理的分布と環境. 日本生態学会誌, 42 , 215-230.

位田真弓 ・波田善夫（2006）岡山県中南部の社叢林植生 一特に岡山県内におけるシイノキ属の生態的特性と分 布傾向一. 岡山理科大学 Naturalistae, no. 10, 35-46. 板野博行 - 竹岳秀陽 - 藤木利之 ·三好教夫 (1994) 瀬戸 内海沿岸堆積物の花粉分布学的研究. 日本生態学会中 国・四国支部 38 回大会要旨, 16.

環境省（2001）第 6 回自然環境保全基礎調査植生調査. 2 次メッシュ「滰宮」「内田」「川東」. 自然環境局生物 多様性センター. http : //www.vegetation.jp/miru/ block/37.html, 2011 年 4 月 4 日引用.

経済企画庁 (1967) 5 万分の 1 土地分類基本調查, 地形分 類図「丸亀」. 国土交通省.

岸本 浩・平野幸代・服部 保・中西 哲（1978）北四 国のシイ型とカゴノキ型の森林. 神戸大学教育学部研 究収録, 60, 17-36.

気象庁 (2002) メッシュ気候值 2000. CD-ROM 版, 気象 業務支援センター。

吉良竜夫（1948）温量指数による垂直的な気候帯のわか ちかたについて一日本の高冷地の合理的利用のため に一. 寒地農学, 2, 143-173.

吉良竜夫 ·安藤萬喜男 · 立花吉茂 $\cdot$ 久礼八郎 - 松井良栄 
（1979）びわ湖とその集水域の環境動態一昭和 53 年度 報告（1)一. 文部省「びわ湖とその集水域の環境動態」 研究班「環境科学」研究報告集: 58-56, 文部省.

久米 修 - 和気俊郎 - 片本 毅 - 新居正敏 - 藤原滝雄 末広喜代一・高橋良平（1987）香川県小豆島地域（含 豊島) の植生. 香川県環境保健部環境自然保護課編 「香川県自然環境保全指標策定調査研究報告書（香川 県小豆島地域) $\rfloor: 11-86$, 香川県.

三好教夫 (1981) シイノキ属, マテバシイ属, クリ属 (ブ ナ科) の花粉の形態. Hikobia Supplement, 1, 381386.

三好教夫 (1982) 走査電子顕微鏡による花粉の形態 4. ブ ナ科（被子植物）について. 岡山理科大学蒜山研究所 研究報告, no. 7, 55-60.

三好教夫（1994）瀬戸内海沿岸低地における植生の変遷 と気候の変動に関する花粉分析学的研究. 平成 4 年度 両備檉園記念財団研究助成金研究報告, 生物学に関す る試験研究論叢, 9, 43-51.

成瀬敏郎・小野間雅巳・村上良典（1985）瀬戸内海, 播 磨灘沿岸における完新世後期の海水準変化に関する資 料. 兵庫教育大学研究紀要, 第 2 分冊, 言語系教育 社会系教育・芸術系教育，5，53-64.

新居正敏 (1992) 香川県の社寺林 (1) 調查法と結果の概 要. 香川生物, $19,75-84$.

岡山県 (1988) 岡山県メッシュ気候図地図編. $51 \mathrm{p}$, 岡山 県.

奥田重俊（1982）香川県の植生. 宮脇 昭編「日本植生 誌」：424-429，至文堂.

Reimer, P.J., Baillie, M.G.L., Bard, E., Bayliss, A., Beck, J.W., Bertrand, C.J.H., Blackwell, P.G., Buck, C.E.,
Burr, G.S., Cutler, K.B., Damon, P.E., Edward, R.L., Fairbanks, R.G., Friedrich, M., Guilderson, T.P., Hogg, A.G., Hughen, K.A., Kromer, B., McCormac, G., Manning, S., Ramsey, C.B., Reimer, R.W., Rammele, S., Southon, J.R., Stuiver, M., Talamo, S., Taylor, F.W., van der Plicht, J. and Weyhenmeyer, C.E. (2004) IntCal04 terrestrial radiocarbon age calibration, 026 cal kyr BP. Radiocarbon, 46, 1029-1058.

佐々木 甫・鈴木茂之（1998）巟島湖干拓地に扮ける ボーリング試料から得られた ${ }^{14} \mathrm{C}$ 年代測定值. 岡山大 学地球科学研究報告, 5, 13-16.

末広喜代一 (1982) 香川県の「温かさの指数」と「寒さ の指数」. 香川生物, $10,39-42$.

末広喜代一 (2007) 香川県の植生. 香川県高等学校生地 部会編「香川の生物」: 13-18, 香川県高等学校生地部 会.

杉山雄一 - 寒川 旭 - 田村栄冶 - 露口耕治 - 藤川 聡 長谷川修一・伊藤 孝・興津昌宏 (2001) 長尾断層 (香川県高松市南方) の活動履歴一三木町水上宮下に おけるトレンチ調查結果一. 活断層・古地震研究報 告, no. 1, 175-198.

高松地方気象台 (2009) 香川県内気象観測平年値表.

http : //www.jma-net.go.jp/takamatsu/4/4-3/heinen. pdf, 2011 年 1 月 27 日引用.

山中二男（1979）日本の森林植生. $219 \mathrm{p}$, 築地書館.

Wessel, P. and Smith, W.H.F. (1998) New, improved version of Generic Mapping Tools released. Eos Transactions, American Geophysical Union, 79 (47), 579. 


\title{
Paleovegetation since the last glacial age based on pollen analysis of a drilling core from Ayagawa Town,
} Kagawa Prefecture, southwest Japan

\author{
Toshinori Matsui*1, a, Masahide Ishizuka*1 and Masahiko Konomatsu*2
}

An 8-m-long drilling core was obtained from the middle part of the Ayagawa River basin, Ayagawa Town, Kagawa Prefecture, northeastern Shikoku Island, Japan. Nine lithofacies were identified in the core, and samples were taken for radiocarbon dating and pollen analysis.

The radiocarbon dating results revealed that upper Pleistocene terrace deposits from $8.00 \mathrm{~m}$ to $3.55 \mathrm{~m}$ depth were overlain by Holocene deposits from $3.55 \mathrm{~m}$ depth to the ground surface.

Pollen of Quercus subgen. Lepidobalanus, which are deciduous broad-leaved trees, was dominant during the middle of the last glacial period, indicating a cool environment in the Ayagawa River basin, whereas during the early postglacial period, the dominance of deciduous broad-leaved tree pollen along with pollen of Quercus subgen. Cyclobalanopsis, which are evergreen broad-leaved trees, indicates a somewhat cool environment. Subsequently, in the later postglacial period, the environment became warm, as is shown by the occurrence of pollen of both subgenus Cyclobalanopsis and Conifers. In general, our results agree with previous results for the Seto Inland Sea region, except for the low occurrence of Castanopsis pollen in the later postglacial period in our results, suggesting that Castanopsis was rare at that time in the upper Ayagawa River basin and that the area around Ayagawa Town was dry, with annual precipitation of less than 1200 $\mathrm{mm}$.

Keywords : pollen analysis, last glacial period, postglacial period, paleoenvironment, Ayagawa Town

\footnotetext{
*1 Faculty of Engineering Kagawa University. 2217-20 Hayashi-cho, Takamatsu, Kagawa, 761-0396, Japan.

*2 Faculty of Education Wakayama University. 930 Sakaedani, Wakayama, 640-8510, Japan.

*a Corresponding author : matsui@ao.kagawa-u.ac.jp
} 